In the Shadow of the Moon 
This page intentionally left blank 


\title{
IN THE SHADOW OF THE MOON
}

THE SCIENCE, MAGIC, AND MYSTERY OF
SOLAR ECLIPSES

ANTHONY AVENI

\author{
Yale \\ UNIVERSITY PRESS
}

New Haven and London 
Published with assistance from the foundation established in memory of Philip Hamilton McMillan of the Class of 1894, Yale College.

Copyright (C) 2017 by Anthony Aveni.

All rights reserved.

This book may not be reproduced, in whole or in part, including illustrations, in any form (beyond that copying permitted by Sections I07 and 108 of the U.S. Copyright Law and except by reviewers for the public press), without written permission from the publishers.

Yale University Press books may be purchased in quantity for educational, business, or promotional use. For information, please e-mail sales.press@ yale.edu (U.S. office) or sales@yaleup.co.uk (U.K. office).

Set in Gotham and Adobe Garamond type by IDS Infotech, Ltd. Printed in the United States of America.

Library of Congress Control Number: 20169538I2 ISBN 978-0-300-22319-4 (hardcover : alk. paper)

A catalogue record for this book is available from the British Library.

This paper meets the requirements of ANSI/NISO Z 39.48-1992 (Permanence of Paper).

IO 98765432 I 
To Ed Maxwell—wise thinker, new friend 
This page intentionally left blank 